\title{
The first finding of diatoms from the Early Miocene lacustrine deposits of the Barguzin Valley (Baikal Rift Zone)
}

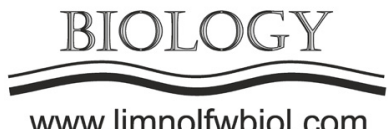

www.limnolfwbiol.com

\author{
Usoltseva M.V. ${ }^{1 *}$, Hassan A. ${ }^{2}$, Rodionova E.V. ${ }^{1}$, Titova L.A. ${ }^{1}$, Chuvashova I.S. ${ }^{2,3}$, \\ Rasskazov S.V. ${ }^{2,3}$ \\ ${ }^{1}$ Limnological Institute Siberian Branch of the Russian Academy of Sciences, Ulan-Batorskaya Str., 3, 664033 Irkutsk, Russia \\ ${ }^{2}$ Irkutsk State University, Irkutsk, Russia \\ ${ }^{3}$ Institute of the Earth's Crust Siberian Branch of the Russian Academy of Sciences, Irkutsk, Russia
}

\begin{abstract}
Using light and scanning electron microscopy, we studied the species composition of diatoms and their distribution in the core hole 545 of the Barguzin Valley. We determined two local diatom zones that reflected the stages of the flora development in the Barguzin Valley during the Early Miocene.
\end{abstract}

Keywords: diatoms, Baikal Rift Zone, Barguzin, Early Miocene

The Barguzin Valley belongs to the central part of the Baikal Rift Zone. It is located northwest of the Svyatoy Nos Peninsula and Barguzin Bay; the Barguzin Range detaches it from Lake Baikal. From east and southeast, the slope of the Ikat mountain ridges surrounds the basin (Fig. 1).

We first published the data on the fossil diatom flora of the Barguzin Valley in (Hassan et al., 2019), where the results of the investigation of diatoms from the cores 532 and 531 revealed four local diatom zones that reflected the development stages of flora in the southern part of the Barguzin Valley from the end of the Middle Miocene to the beginning of the Pliocene.

This work presents the results of the study diatoms from the core 545, which was obtained in 2012 near the Uro settlement (southwesten part of the valley) by the Baikal Branch of Joint Stock Company "Urangeologorazvedka". The study aimed to search for the most ancient diatoms in the Baikal region.

Using light and scanning electron microscopy, we investigated species diversity of diatoms and their distribution in the core. In total, we identified 36 species, among which 8 were extinct. Planktonic diatoms dominated along the entire section. Their species composition has changed. Based on the appearance or disappearance of indicator species, we determined two local diatom zones (Fig. 2).

Diatom zone 1 was determined from the dominance of the oval Alveolophora sp. 1 valves in the depth interval (170.0-160.0 m). This is a planktonic species with an unidentified taxonomic status, which will be described as novel to science. It was $90-99 \%$ of the total number of diatoms. The maximum number of valves of this species was recorded in the lower part of the core (169 m), accounting for 228 million valves/g. Above, in the interval of $168-161 \mathrm{~m}$, the number of valves varied from 1.5 to 65 million valves/g. Accompanying species were Alveolophora baicalensis Khursevich et Fedenya (1-1.9\%) and Alveolophora antiqua (Moiseeva) (0.01\%). Another planktonic species, Actinocyclus styliferum Khursevich et Fedenya, was found together with Alveolophora sp. 1 at 163 and $161 \mathrm{~m}$, amounting to 6.5 and 0.8 million valves $/ \mathrm{g}$, respectively.

Among the littoral species, there were single specimens of Ellerbekia kochii (Pant.) Moiss. The species Skabitschewskia oestrupii (Cleve) Kuliskovskiy et LangeBertalot, Staurosira subsalina (Hustedt) Lange-Bertalot,

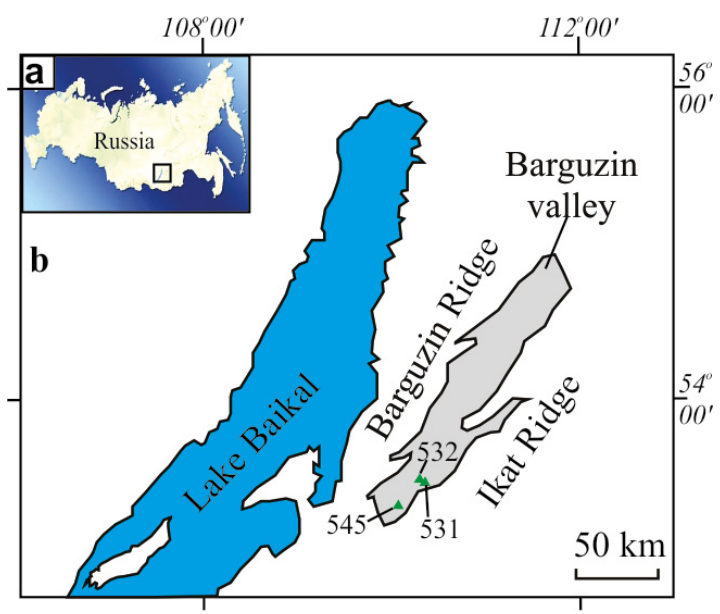

Fig.1. Location of the Barguzin Valley and cores 545, 532 and 531

*Corresponding author.

E-mail address: usmarina@inbox.ru (M.V. Usoltseva)

(C) Author(s) 2020. This work is distributed under the Creative Commons Attribution 4.0 License. 


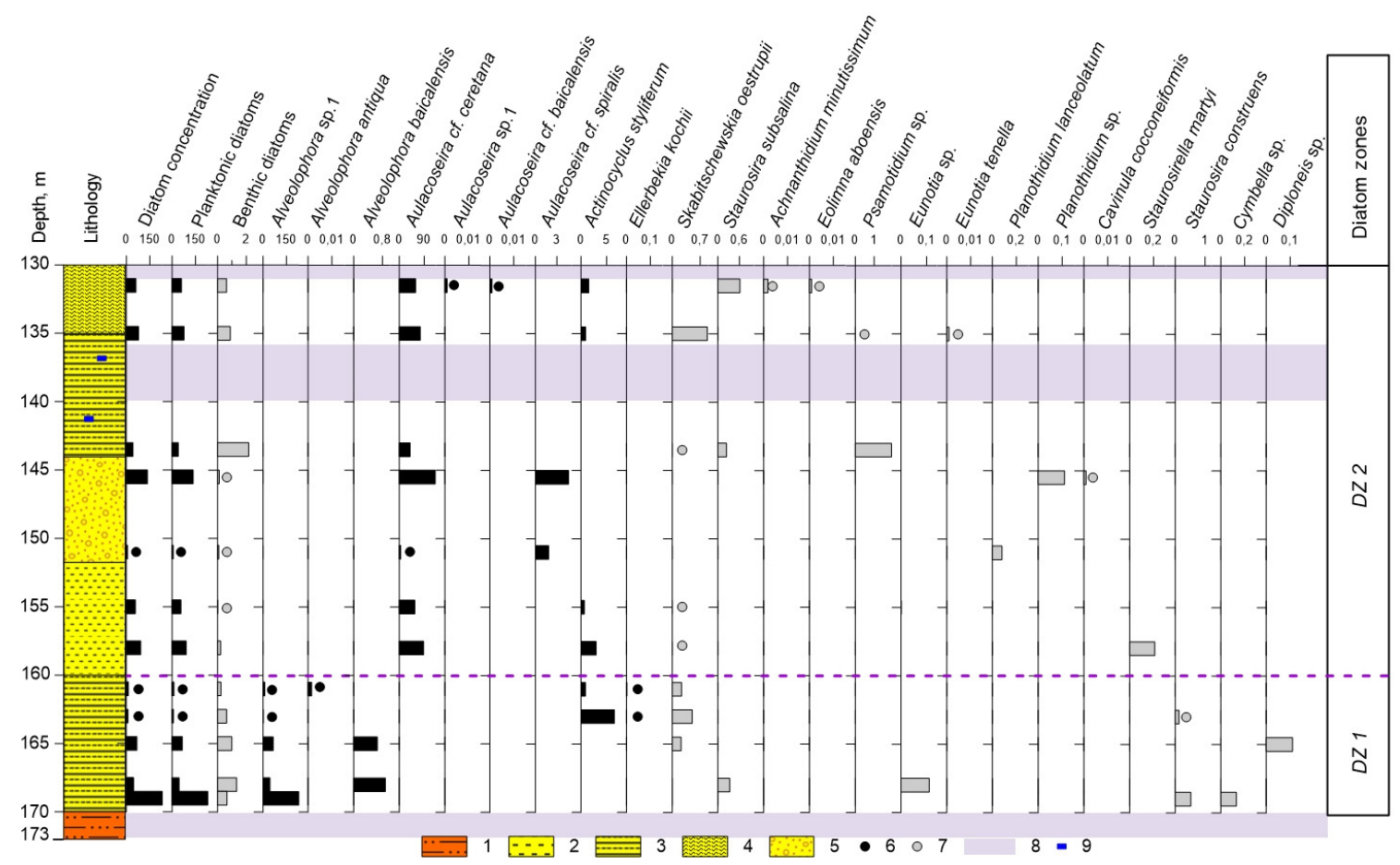

Fig.2. Distribution of diatoms in lacustrine sediments of the core 545. Relative abundances of the main diatom species are concentrations of valves (millions) in $1 \mathrm{~g}$ of dry sediment. 1 - pre-Tankhoy unit; 2-5- lacustrine unit of Tankhoy formation: 2 - mudstone, 3 - silty mudstone, 4 - siltstone, 5 - sandstone; 6-7 - small amount: 6 - planktonic diatoms, 7 - benthic diatoms; 8 - no diatoms; 9 - vivianite.

Staurosira construens Ehrenberg, Tetracyclus glans (Ehrenberg) Mills, Eunotia sp. Cymbella sp., Diploneis sp., etc. represented benthic diatoms in a small amount (up to $7.2 \%$ ).

Diatom zone 2 was determined from the disappearance of Alveolophora and appearance of Aulacoseira in the depth interval of 160.0-130.0 m. Aulacoseira cf. ceretana E.Y. Haworth et Sabater was the dominant species in this zone. Its number varied from 5 to 130 million valves/g, which was $8.9-72 \%$ of the total number of diatoms. Other species, Aulacoseira cf. spiralis (Ehrenberg) Houk et Klee, Aulacoseira sp.1 and Aulacoseira cf. baicalensis (Wislouch) Simonsen, were found in separate layers in a small amount. The number of Actinocyclus styliferum in this zone was 0.019.3 million valves $/ g$.

Benthic diatoms were less than $5.2 \%$ of the total number of diatoms. They were represented by the following species: S. oestrupii, Eunotia tenella (Grunow) Husted, S. subsalina, Achnanthidium minutissimum (Kützing) Czarnecki, Eolimna aboensis (Cleve) Genkal, Planothidium lanceolatum (Brébisson ex Kützing) Lange-Bertalot, Psamotidium sp., Gomphosphenia grovei var. lingulata (Hustedt) Lange-Bertalot, Punctastriata lancettula (Schumann) Hamilton et Siver, Ensyonema silesiacum (Bleisch) Mann, Cavinula cocconeiformis (Gregory ex Greville) Mann et Stickle, and Staurosirella martyi (Héribaud-Joseph) Morales et Manoylov.

Comparison of the obtained species complexes with the published data on the Baikal region (Rasskazov et al., 2007; Kuzmin et al., 2009; Usoltseva et al., 2019) revealed that the species composition of the core 545 differs from those investigated previously and is more ancient, the Early Miocene. The greater wall thickness of the frustule, the deep annular diaphragm of the Aulacoseira species and oval valves of Alveolophora sp. 1 indicate this fact. The latter ones are known from the Early Miocene deposits of the Far East, Japan and Oregon in the USA (Usoltseva et al., 2013). Such an estimate of the age corresponds to deposit dating based on palynological data (Rasskazov et al., 2019) and the low stratigraphic position of the layers in the section.

\section{Acknowledgements}

This work was supported by RFBR Grant No. 19-04-00746 and project No. 0345-2019-0001 in the Electron Microscopy Center of Collective Instrumental Center 'Ultramicroanalysis' at Limnological Institute Siberian Branch of the Russian Academy of Sciences.

\section{References}

Hassan A., Usoltseva M., Rasskazov S. et al. 2019. First study of fossil diatom flora from Middle MioceneLower Pliocene lacustrine sediments in Barguzin Valley, Baikal Rift Zone. Quaternary International 524: 24-30. DOI: 10.1016/j.quaint.2019.03.024

Kuzmin M.I., Khursevich G.K., Prokopenko A.A. et al. 2009. Tsentricheskiye diatomovyye vodorosli pozdnego kaynozoya ozera Baykal: morfologiya, sistematika, stratigraficheskoye rasprostraneniye, etapnost' razvitiya (po materialam glubokovodnogo bureniya) [Late Cenozoic centric diatoms of Lake Baikal: morphology, taxonomy, stratigraphic distribution, stages of development (based on the materials of deep- 
sea drilling)]. Novosibirsk: Academic Publishing House Geo. (in Russian)

Rasskazov S.V., Lyamina N.A., Chernyaeva G.P. et al. 2007. Stratigrafiya kaynozoya Vitimskogo ploskogor'ya. Fenomen dlitel'nogo riftogeneza na yuge Vostochnoy Sibiri [Cenozoic stratigraphy of the Vitim Plateau. Phenomenon of long-term rifting in the South of East Siberia]. Novosibirsk: Academic Publishing House Geo. (in Russian)

Rasskazov S.V, Tregub T.F., Volkov M.A. 2019. Palynological characteristics of the alluvial formations of the valley Barguzin river. Vestnik Voronezhskogo Gosudarstvennogo Universiteta. Seriya: Geologiya [Proceedings of Voronezh State University. Series: Geology] 2: 150-152. (in Russian)

Usoltseva M.V., Titova L.A., Hassan A. et al. 2019. Centric diatoms from paleolakes of the Baikal rift zone, Russia. Voprosy Sovremennoi Algologii [Issues of Modern Algology] 2: 279-284. DOI: 10.33624/23110147-2019-2(20)-279-284

Usoltseva M.V., Kociolek J.P., Khursevich G.K. 2013. Three new species of Alveolophora (Aulacoseiraceae, Bacillariophyceae) from Miocene deposits in western North America. Phycologia 52: 109-117. DOI: 10.2216/12-022.1 